\title{
31 Entrepreneurship as an economic development strategy for agricultural transformation in Southern Africa
}

\author{
Ralph D. Christy and Mohammad Karaan
}

\section{Introduction}

Entrepreneurs ${ }^{1}$ are recognized globally for their contribution to economic growth. Frequently, entrepreneurs within agribusiness industries are described as the "engines" of emerging economies as demonstrated by their innovations, job and wealth creation, usage of local or domestic resources, facilitation of industrialization and promotion of rural and urban development (Christy et al., 2015). Opportunities in agribusiness in Africa's emerging economies have expanded tremendously due to globalization, regional trade agreements and urbanization. With increased globalization, consumer trends such as changes in food preferences and increased food purchases at supermarkets are occurring across many African countries. While globalization is changing consumers' preferences, urbanization is changing the way food is produced and marketed in Africa. As agribusiness entrepreneurs offer products and services to urban areas, new technologies are emerging to develop value-added food products that meet the demands of African consumers. At the same time, forces such as competition from global business players and climate change pose new challenges to owners and managers of African agribusiness companies.

Despite those market opportunities and challenges, capacity strengthening programmes for agricultural development in Africa traditionally have focused on production directed towards achieving food security objectives. For agribusiness companies to remain competitive, new capacity strengthening strategies and training programmes are needed to address the challenges faced by managers. With the steady growth of the food value-addition and service sectors, more investments are needed to strengthen the capacity of local agribusiness managers so that they may effectively contribute to the sustainable growth and development of African economies. Addressing this capacity gap is a primary goal of the Making Markets Matter (MMM) training programme that was started in 2001 at Stellenbosch University.

This chapter will provide a conceptual understanding of entrepreneurship as a driver for agricultural transformation and economic development in southern Africa as well as an overview of alternative capacity strengthening programmes for business development for small firms in emerging economies. 


\section{The role of SMEs in economic development: theory and conceptual frameworks}

Despite general support for SMEs programmes, until recently, scholars had given little attention to understanding entrepreneurship as the basis for a comprehensive economic development strategy. Over the years, scholars and development practitioners have accumulated a body of knowledge about the economic development process, but this literature fails to provide a coherent conceptual understanding of how to generate entrepreneurship and sustainable economic progress. Clarity regarding the very role of entrepreneurship and its impact on economic development is also lacking.

Schumpeter's The Theory of Economic Development, first published in 1911, links innovation and the entrepreneur, claiming that successful innovation is the source of private profits, which in turn lead to economic growth. The entrepreneur creates new economic combinations by: 1) introducing new products; 2) introducing new production functions that decrease inputs needed to produce a given output; 3) opening new markets; 4) exploiting new sources of materials; and 5) reorganizing an industry (Schumpeter, 1961; Nafziger, 1997). Given Schumpeter's conceptual claims, many empirical gaps are apparent in entrepreneurship research. First, a standard definition for an entrepreneur does not exist. Second, data is unavailable to allow researchers to compare entrepreneurial activity between nations and the data that was available lacked information about a population's entrepreneurial qualities. Third, for international comparisons, data was unavailable about the business start-up process. Until the past decade or so, scholars were unable to make international comparisons of entrepreneurial activity rates or offer a framework for evaluating their conditions.

More recently, researchers have started giving more attention to the connection between entrepreneur or small business development and economic growth. The Global Entrepreneurship Monitor (GEM), a joint research initiative of Babson College in Wellesley and the London Business School, was one group that investigated this new discipline of "entrepreneurial academics". The GEM collected and analyzed data about entrepreneurship and business development globally. The initiative aimed to determine the variance of entrepreneurial activity between countries, the reasons some countries have higher entrepreneurship rates than others, the types of national policies that can increase entrepreneurial activity and the connection between entrepreneurship and economic growth. At the country level, the GEM created a model that identifies nine determinants of entrepreneurial opportunities including: financial support, government policies, government programmes, education and training, research and development transfer, commercial/professional infrastructure, barriers to market entry, access to physical infrastructure and cultural and social norms.

Many development scholars and professionals believe supporting small businesses in emerging economies can be an effective tool to alleviate poverty and sustain a healthy economy (Lichtenstein and Lyons, 2001; Acs and Malecki, 
2003). A small but critical portion of new businesses bring knowledge, products or ways of producing goods or services to a community. A greater number of new businesses, in turn, widen the distribution of new goods and services developed by other entrepreneurs. Recent studies have found also that the impact of new business development differs depending on the stage of a country's economic development. One study, which examined data from 36 countries found a U-shaped relationship between new entrepreneurship and the level of economic development (Wennekers et al., 2005). A country's entrepreneurship rate initially declines as its economy develops but then levels off or rises again after it reaches a certain level of development.

Arenius and DeClercq (2005) found that people with higher levels of education are more likely to identify entrepreneurial opportunities than those with lower education levels. Therefore, one policy option could be to foster an environment that facilitates the exchange of information among people who are interested in or knowledgeable about entrepreneurship. This strategy would have to consider a community's entrepreneurial history and specific context to be effective.

Entrepreneurs sometimes have advantages facilitated by wealth or status in society, which are influenced by factors such as: 1) access to more information than competitors; 2) access to training and education; 3) local elites or family connections; 4) access to government; and 5) agreements to restrict entry or output. Entrepreneurial activity is a means for moving up the economic ladder allowing the socioeconomic status of the entrepreneurs to be higher than their parents (Nafziger, 1997). Most studies have shown a higher level of education among entrepreneurs relative to the population at large. Achievements in verbal, mathematical, written and problem-solving skills have contributed to entrepreneurial success, though the time it takes to obtain these, and lengthy apprenticeships, can be costly. In areas where educational opportunities are lacking, individuals tend to accept "secure positions" with high earnings and low risk. Alternatively, areas with a surplus of university graduates tend to encourage entrepreneurship in avoidance of unemployment or low-paying work. Further, cultural norms in transition economies dictate expectations for men and women in the business setting. Those traditional norms often inhibit women's access and success. The characteristics of a successful entrepreneur are inconsistent with what some societies expect of women. Refusal of credits by banks and input suppliers may further hinder women entrepreneurs.

Very often it is the case that business development in emerging economies, especially in low-income communities, is challenged by the very circumstances it aims to eradicate. Poverty coincides with, and most likely contributes to, a deficient state of enterprise development. Increasingly, however, development experts argue that small enterprise development in those settings has a greater likelihood of sustainability than traditional, more costly approaches that seek to attract external businesses to the area. The major contribution of business development to increased community welfare is the generation of new jobs and additional income. A substantial body of evidence suggests that the small business sector has yielded the bulk of new jobs (Acs, 1999). Given this 
evidence, entrepreneurship as an economic development strategy has continued to gain credibility as governments and donor agencies have expanded funding for entrepreneurship development programmes. This development strategy is perhaps the first major economic development paradigm to be simultaneously applied to low-income areas in both developed and developing economies.

Due to globalization and the competition from lower transaction costs in other countries, efforts to attract businesses from other regions has not always worked. Increasingly, community activists and policymakers are calling for development strategies that focus on homegrown small firms, regional trade associations and local entrepreneurs. They argue that local entrepreneurs are often neglected as agents of development and support a shift in focus to supporting entrepreneurship from "within their communities" rather than trying to attract outside businesses. This notion is backed by a growing body of theory and research that reexamines the "bigger is better" model and emphasizes the organizational embeddedness of small-scale, locally controlled economic enterprises (Robinson et al., 2002). Moreover, it suggests that the establishment of more entrepreneurship-centred economic development may enable economically disadvantaged communities to reverse stagnant economic conditions by creating wealth and jobs through locally owned businesses.

Heated debates have long existed in development economics about the appropriate roles of government, business, individual innovators and civil society in fostering long-term economic growth and poverty reduction. A clear understanding of development policy objectives and strategies are needed as successful economic development is predicated on the design of "institutions" that will establish both effective public policies and successful private strategies.

\section{An alternative capacity strengthening model for SME development}

To foster development in economically depressed areas, it is important to have public policies that support healthy entrepreneurial ecosystems. ${ }^{2}$ Programmes should focus on retaining financial capital, encouraging business development and providing incentives to curb out-migration and encourage in-migration of skilled people. Examples of instruments or "policy levers" to achieve those objectives include capital subsidies, infrastructure improvements, tax breaks and relaxed regulations for businesses, human capital development and management training. Beyond those traditional strategies, enlightened public policy must also build upon the existing "social capital" in economically depressed regions. Analysts contend that governments can create a favourable growth climate or "enabling environment' by using public funds to provide infrastructure to support genuinely profitable businesses. The Porter (1995) model of economic development offers principles that underline a sound small business-centred strategy:

- Economic rather than social focus that emphasizes the creation of wealth instead of the redistribution of wealth in economically disadvantaged communities 
- Emphasis on the private sector with recognition of the supporting and complementary roles played by the government and social service sectors

- Emphasis on engaging skilled and experienced individuals in entrepreneurial activities.

The goal of Porter's model is to identify and exploit the competitive advantages of regions that will translate into truly profitable businesses. For this model to be effective, governments must support the private sector in new economic initiatives, shifting focus from direct intervention to the facilitation of a favourable business environment (or ecosystem).

Since 2001, Stellenbosch and Cornell University have partnered to organize the MMM workshop, an alternative approach to entrepreneurial capacity strengthening based on a contemporary conceptualization of programme design and programme evaluation to monitor transformative change. As we engage African agribusinesses, recognizing that learning will vary across cultures and contexts, we consider all aspects of an empowering educational experience context, method, philosophy, content, process and the role of the facilitators. Because lasting and sustainable change often comes through a society's educational system, our approach is centred on the participants' needs, questions and curiosity. To ensure effectiveness and impact, the MMM workshop focuses on learning based on African case studies (Mabaya et al., 2011) that provide the participants the opportunity to discover solutions to the problems and challenges they often face in their own businesses. We therefore developed a framework with an emphasis on new and innovative approaches to entrepreneurial capacity strengthening as distinct from the traditional model of thinking about executive programmes. The key features the MMM workshop are outlined in Table 31.1.

What makes the MMM approach unique? Simply put, it is the combination of the key aspects that will affect a company's bottom line, viewed through the lens of both industry and academia. We look beyond the individual and focus on the company as a unit to ensure that change and benefits are systemic for agribusinesses to function effectively. Ultimately, it is the individuals, working

Table 31.1 MMM approach to SME capacity strengthening framework

\begin{tabular}{lll}
\hline Description & Traditional approach & Integrated training programme \\
\hline Unit of analysis & Individual & Company/organizational capacity \\
Methods & Lectures & Case studies/team building/presentations \\
Strategy & Clusters & Network development \\
Problem focus & Market access & Technology, market and capital access \\
Partners & Ngos & Business Schools, ngos, Corporations and \\
& & Governments \\
Facilitators & International & Hybrid - International, Regional and Local \\
$\begin{array}{l}\text { Monitoring and } \\
\text { evaluation }\end{array}$ & External indicators & Participatory assessment \\
\hline
\end{tabular}

Source: Authors 
as a team committed to the same mission and goals, who will expand and grow the company. Additionally, to be successful, African agribusiness must keep up with industry changes and technological innovation, stay ahead of competitors, build and manage knowledge, empower and retain employees, among many things. Thus, our focus on the organizational capacity, as a whole, adds more value and impact. Sometimes, the focus on individual capacity and mentoring, in high turnover environments, can be also a poor use of resources.

Our methods are learner-centred. The use of case studies (Mabaya et al., 2011; Christy et al., 2018) helps participants learn from practical, real life examples and experiences. This approach moves them from focusing on the problems exclusively to engaging with the questions, solutions and applications. The use of other participatory methods such as role-playing, small group discussions and team building activities is very effective in this process of learning.

The emphasis on business networks as opposed to clusters grows out of MMM's years of engagement with African entrepreneurs. We have found that "unlike clusters - which are defined within and often limited by physical location - networks are not bound by geography" (Da Silva and Mhlanga, 2011). Our MMM target audience comes from southern Africa (and beyond) and has a strong desire to connect to and access global markets. Thus, the business networks are more relevant and beneficial for the participants in connecting to local, regional and global networks to access diverse markets.

This focus on business networks also builds on MMM's ability to build collaborative approaches between industry and academia. Traditionally, executive education programmes have tilted towards nongovernmental organizations (NGOs). However, bringing together the best thinking in top business schools, industry, governments and NGOs ensures that the gaps in skillsets and knowledge within African agribusinesses are addressed.

Finally, the MMM workshop has a rigorous monitoring and evaluation to ensure impact and effectiveness. MMM's integrated training programme ensures that the process of learning (inputs, activities and outputs) can augment company performance and better the quality of life for agribusinesses owners, employees and their families as well as communities across Southern Africa. MMM's four primary objectives are to:

- Enhance the business management capacity of African entrepreneurs through the combination of short-term, intensive, capacity strengthening and longer-term leadership coaching

- Facilitate business and strategic linkages between companies and the broader agribusiness sector in Africa

- Provide an opportunity to network by showcasing and marketing products and services or sharing information materials

- Integrate industry analysis and case studies of selected companies.

The programme combines a structured learning environment featuring conceptual frameworks and analytical techniques for decision making, contemporary 
African agribusiness-specific case studies and the opportunity to share ideas with and learn from peers representing the African continent. As part of establishing business networks and market access, participants are also encouraged to participate in the MMM Product Expo. At the end of the official program, each participant has the opportunity to visit an agribusiness firm as part of a company site visit which includes engagement with management. With all those integrated components, the program's ultimate goal is to improve socioeconomic conditions in communities by strengthening emerging entrepreneurs in Africa through an innovative and multifaceted initiative that seeks to improve the performances of their businesses.

\section{Conclusion}

Entrepreneurship refers to both owning and managing a business at one's own risk to take advantage of an economic opportunity. Global competition and corporate restructuring have prompted development scholars to increasingly focus on entrepreneurship as an area of policy and practice. Development literature has historically focused on the roles of the market and the state in the economic development process. More recent literature highlights the role of civil society in development. The potential for civic organizations to facilitate revitalization opportunities beyond what the market and political institutions can offer is gaining increasing recognition. Development practitioners have begun to realize the importance of incorporating and building upon local civic organizations for economic, social and political activities. Sustainable economic growth strategies can no longer separate enterprise innovation from advances in government and civic institutions. Innovations must be reinforced in and complemented by all three sectors to advance a supporting ecosystem for entrepreneurs.

Business development services, important for creating private sector capacity in emerging markets, require experiential knowledge that should be available to employees as well. Many entrepreneurs in Africa face a scarcity of skilled individuals within their local areas. Due to the limited amount of educational opportunities and economic growth potential, depressed areas often experience a "brain drain", in which skilled and educated individuals leave in search of a more lucrative environment. Cultural norms oftentimes prohibit women from achieving the same level of skill and professionalism that is available to men in their societies. To overcome internal and external challenges facing African entrepreneurs, capacity strengthening programmes must create training workshops that are innovative, practical and highly relevant.

\section{Notes}

1 The terms entrepreneur, small business, small and medium enterprise (SME), microbusiness, and agri-preneur have been used interchangeably in many contexts depending on which country is defining the term. Some measures that are used to define this term include number of people employed, capital employed, and sales turnover. 
2 An entrepreneurial ecosystem is "a set of interdependent actors and factors coordinated in such a way that they enable productive entrepreneurship within a particular territory" (Stam and Spigel, 2016). This approach to understanding the environment around entrepreneurs as well as entrepreneurship in an economy builds upon ideas from the regional development literature as well as the strategy literature. For a brief overview, see: Stam and Spigel, 2016; Acs, Stam, Audretsch, and O'Connor, 2017.

\section{References}

Acs, Zoltan J. (Ed.) (1999), Are Small Firms Important? Their Role and Impact. Boston, MA: Kluwer Academic Publishers and U.S. Small Business Administration.

Acs, Zoltan J. and Edward J. Malecki (2003), Entrepreneurship in Rural America: The Big Picture. Kansas City, MO: Federal Reserve Bank of Kansas City.

Acs, Zoltan J., Erik Stam, David B. Audretsch, and Allan O'Connor (2017), “The Lineages of the Entrepreneurial Ecosystem Approach," Small Business Economics, 49(1), 1-10.

Arenius, Pia, and Dirk De Clercq (2005), "A Network-Based Approach on Opportunity Recognition," Small Business Economics, 24(3), 249-65.

Christy, Ralph, Joselito Bernardo, Aimée Hampel-Milagrosa, and Lin Fu (Eds.) (2018), Asian Agribusiness Management: Case Studies in Growth, Marketing, and Upgrading Strategies. Singapore: World Scientific.

Christy, Ralph, Mohammad Karaan, Edward Mabaya and Krisztina Tihanyi (Eds.) (2015), From Principles to Best Practices: A "Making Markets Matter" Guide to Managing African Agribusinesses. Ithaca, NY: Market Matters Inc.

Da Silva, Carlos A. and Nomathemba Mhlanga (2011), Innovative Policies and Institutions to Support Agro-Industries Development. Rome: Food and Agriculture Organizations (FAO).

Lichtenstein, Gregg A. and Thomas S. Lyons (2001), “The Entrepreneurial Development System: Transforming Business Talent and Community Economies," Economic Development Quarterly, 15(1), 3-20.

Mabaya, Edward, Krisztina Tihanyi, Mohammad Karaan and Johan van Rooyen (Eds.) (2011), Case Studies of Emerging Farmers and Agribusinesses in South Africa. Stellenbosch, South Africa: Sun Press.

Nafziger, Wayne (1997), The Economics of Developing Countries. Upper Saddle River, NJ: Prentice Hall.

Porter, Michael E. (1995), “The Competitive Advantage of the Inner City," Harvard Business Review, 73(3), 55-71.

Robinson, Kenneth L., Thomas A. Lyson, and Ralph D. Christy (2002), "Civic Community Approaches to Rural Development in the South: Economic Growth with Prosperity," Journal of Agriculture and Applied Economics, 34(2), 327-338.

Schumpeter, Joseph. (1961), The Theory of Economic Development: An Inquiry into Profits, Capital, Credit, Interest, and the Business Cycle (Redvers Opie, Trans.). New York: Oxford University Press.

Stam, Erik, and Ben Spigel (2016), "Entrepreneurial Ecosystems," Utrecht University School of Economics (USE) Discussion Paper Series Nr: 16-13.

Wennekers, Sander, André Van Wennekers, Roy Thurik, and Paul Reynolds (2005), "Nascent Entrepreneurship and the Level of Economic Development," Small Business Economics, 24(3), 293-309. 